\title{
Origin of the Diastereoselectivity of the Heterogeneous Hydrogenation of a Substituted Indolizine
}

\author{
Rodrigo A. Cormanich, Lucas A. Zeoly, Hugo Santos, Nilton S. Camilo, Michael Bühl,
} and Fernando Coelho*

Cite This: J. Org. Chem. 2020, 85, 11541-11548

Read Online

\section{ACCESS | \\ 山ll Metrics \& More \\ Article Recommendations \\ Supporting Information}

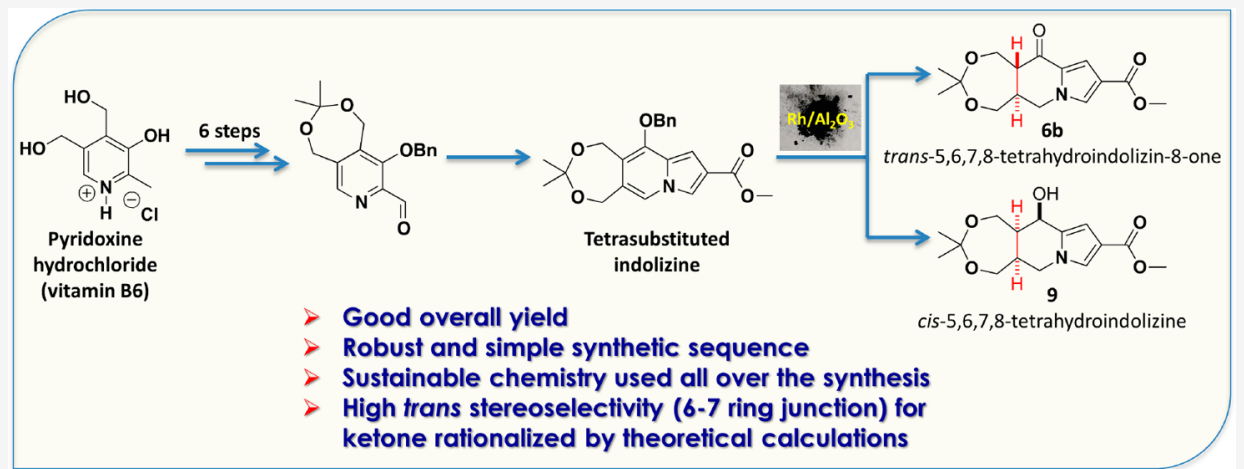

ABSTRACT: In this work, the stereoselective heterogeneous hydrogenation of a tetrasubstituted indolizine was studied. Partial hydrogenation products were obtained in three steps from a substituted pyridine-2-carboxaldehyde prepared from commercial pyridoxine hydrochloride. The hydrogenation of the indolizine ring was shown to be diastereoselective, forming trans-6 $\mathbf{b}$ and cis-9. Theoretical calculations ( $a b$ initio and DFT) were used to rationalize the unusual trans stereoselectivity for $\mathbf{6 b}$, and a keto-enol tautomerism under kinetic control has been proposed as the source of diastereoselectivity.

Naturally occurring 5,6,7,8-tetrahydroindolizinones, bicyclic compounds characterized by a pyrrole ring fused to a 6membered saturated chain, a bridgehead nitrogen atom, and a ketone moiety, are of rare occurrence in nature, even though their indolizidine saturated analogues are abundant in alkaloid chemistry. ${ }^{1}$

For instance, the isolation of the first natural 5,6,7,8tetrahydroindolizinone was reported only in 1997, when polygonatine B (1) was isolated from the liliaceous plant Polygonatum sibiricum (Figure 1$)^{2}$ and from Polygonatum kingianum, along with the homologue kinganone (2). ${ }^{3}$ Polygonatine A (3), the hydroxymethyl parent of both 1 and 2, was also isolated from $P$. sibiricum. ${ }^{4}$ Both $\mathbf{1}$ and $\mathbf{2}$ exhibited
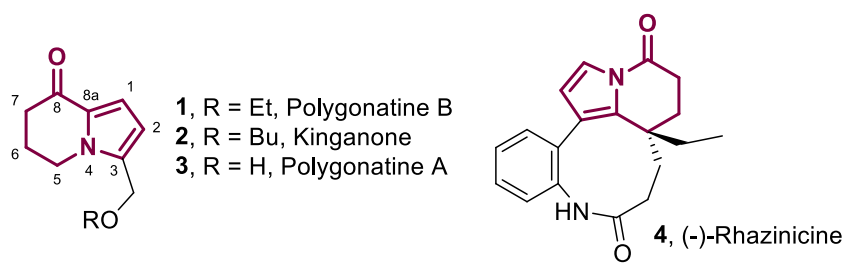

Figure 1. Naturally occurring 5,6,7,8-tetrahydroindolizinone derivatives. antimicrobial and antifungal activities against a range of microorganisms. ${ }^{3}$

Furthermore, (-)-rhazinicine (4), 5,6 an alkaloid containing the 5,6,7,8-tetrahydroindolizin-5-one motif, showed an antitumor activity similar to that of taxol (Figure 1$)^{7}$

Unlike 5,6,7,8-tetrahydroindolizines, whose preparations have been achieved by efficient procedures in the literature, ${ }^{8,9}$ there are only a few protocols reported for 5,6,7,8tetrahydroindolizinone synthesis. ${ }^{10,11}$ More specifically, the synthesis of compounds containing a 5,6,7,8-tetrahydroindolizin-8-one core (also named 6,7-dihydro-8 $(5 H)$-indolizinone) has been scarcely explored, ${ }^{11}$ with most of the approaches relying on Friedel-Crafts acylation. ${ }^{11 \mathrm{a}-\mathrm{h}}$ To the best of our knowledge, there are no reports on 5,6,7,8-tetrahydroindolizinone preparation directly through partial hydrogenation of an indolizine.

Received: June 5, 2020

Published: August 11, 2020 
Scheme 1. Synthetic Approach to Tetrahydroindolizinone 6 and Tetrahydroindolizine $9^{a}$

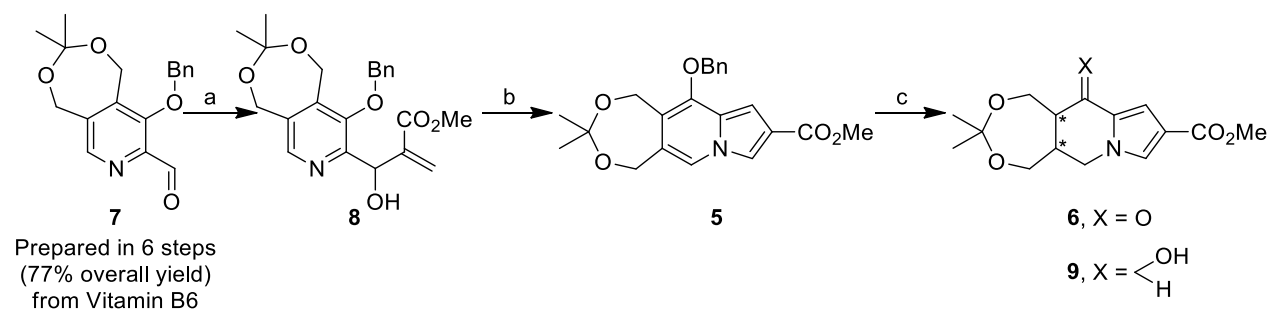

${ }^{a}$ Reaction conditions: (a) DABCO (0.65 equiv), methyl acrylate (20 equiv), ultrasound, rt, $64 \mathrm{~h}(85 \%) ;(\mathrm{b}) \mathrm{Ac}_{2} \mathrm{O}, 100{ }^{\circ} \mathrm{C}, 19 \mathrm{~h}(65 \%) ;(\mathrm{c}) \mathrm{Rh} /$ $\mathrm{Al}_{2} \mathrm{O}_{3}(10 \% \mathrm{w} / \mathrm{w}), \mathrm{H}_{2}$ (80 bar), EtOAc, rt, $48 \mathrm{~h}$ (30\% for $\left.\mathbf{6 b}\right)$.

Scheme 2. Heterogeneous Hydrogenation of Indolizine 5

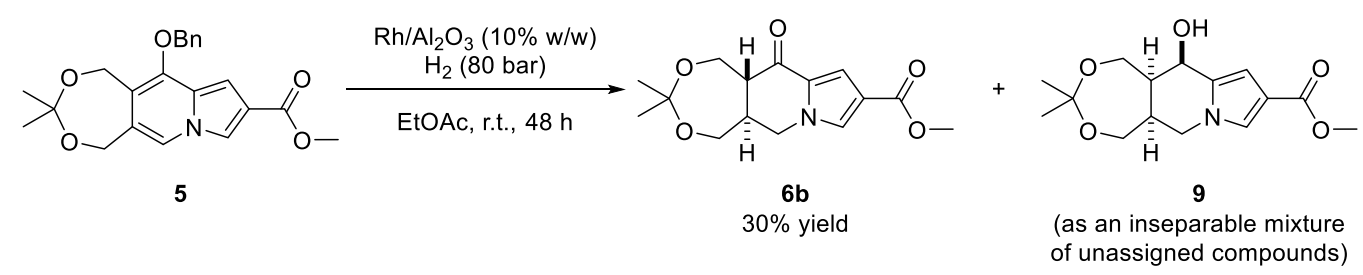

Scheme 3. Mechanistic Hypothesis for the Hydrogenation Step Using $\mathrm{Rh} / \mathrm{Al}_{2} \mathrm{O}_{3}$ as Catalyst

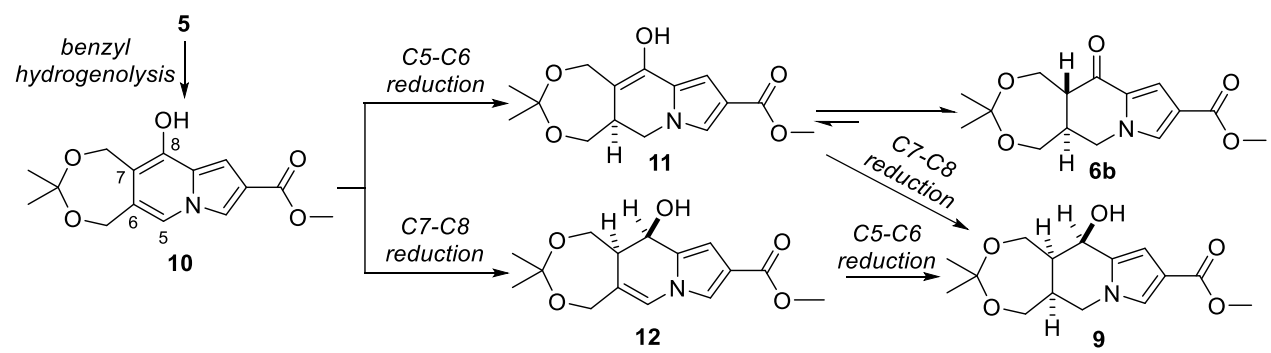

In this work, we describe the results of a highly trans diastereoselective heterogeneous hydrogenation reaction of the tetrasubstituted indolizine $\mathbf{5}$ to prepare polyfunctionalized 5,6,7,8-tetrahydroindolizin-8-one 6 (Scheme 1). This transformation was rationalized by theoretical calculations, which suggested a keto-enol tautomerism as the source of the observed stereoselectivity, favoring the kinetic product.

The starting material for our synthetic route was pyridoxine hydrochloride-also known as vitamin B6-which, despite its polyfunctionalized structure, is a low-cost compound (>US \$1 per gram). ${ }^{12}$ We envisaged that the presence of hydroxyl groups of different reactivities in vitamin B6 could potentially be explored for the preparation of new tetrahydroindolizinone and tetrahydroindolizine motifs.

The synthetic route developed for the synthesis of the 5,6,7,8-tetrahydroindolizinone $\mathbf{6}$ was carefully planned to avoid chromatographic purification in most of its steps. Furthermore, most of the sequence was carried out on a multigram scale through low cost and efficient reactions. Thus, functionalized pyridine-2-carboxaldehyde 7 was prepared in six steps and $77 \%$ overall yield by using a quite robust, modified procedure reported several decades ago by Korytnyk et al. (Scheme 1). ${ }^{13}$ The presence of the seven-membered cyclic acetal in 7 is essential, since it is key to the observed diastereoselectivity in the heterogeneous hydrogenation step, as will be discussed later. No chromatographic purification was required for the preparation of 7 , which was sufficiently pure by NMR spectrum to be used in the next reaction step.
The Morita-Baylis-Hillman ( $\mathrm{MBH}$ ) reaction of compound 7 with methyl acrylate, a key step of our approach, was performed using a protocol developed by our laboratory involving the use of ultrasound to speed up the reaction. ${ }^{14}$ Adduct 8 was obtained in $85 \%$ yield after $64 \mathrm{~h}$, and the crude product was used in the next reaction step without further purification. Then, we turned our attention to prepare indolizine 5. Several literature methodologies describe the synthesis of indolizines from $\mathrm{MBH}$ adducts. ${ }^{9,15} \mathrm{We}$ initially opted to test some of them, and the best result was achieved by heating the $\mathrm{MBH}$ adduct to $100{ }^{\circ} \mathrm{C}$ in acetic anhydride medium. Some byproducts were formed in this step, and chromatographic purification was necessary to obtain pure $\mathbf{5}$ in $65 \%$ yield.

Once indolizine 5 was prepared, the performance of the partial hydrogenation reaction was evaluated by screening reaction parameters such as heterogeneous catalysts, $\mathrm{H}_{2}$ pressures, and solvents (see the Supporting Information for more details). ${ }^{9}$ When $\mathrm{Rh} / \mathrm{Al}_{2} \mathrm{O}_{3}$ was used as a catalyst in ethyl acetate at 80 bar of $\mathrm{H}_{2}$ pressure and room temperature, starting material 5 was fully consumed after $48 \mathrm{~h}$, furnishing a mixture of three main compounds (as determined by ${ }^{1} \mathrm{H}$ NMR). Compound $\mathbf{6 b}$ could be separated and isolated in $30 \%$ yield, while alcohol 9 was obtained as an inseparable mixture (see the Supporting Information for full structural assignment) (Scheme 2).

Compound $\mathbf{6 b}$ and the mixture containing 9 were fully characterized by ${ }^{1} \mathrm{H},{ }^{13} \mathrm{C}\left\{{ }^{1} \mathrm{H}\right\}$ NMR, ${ }^{1} \mathrm{H}-{ }^{1} \mathrm{H}$ COSY, ${ }^{1} \mathrm{H}-{ }^{13} \mathrm{C}$ HSQC, and ${ }^{1} \mathrm{H}-{ }^{13} \mathrm{C} \mathrm{HMBC}$ experiments, and their relative 
stereochemistries were assigned using ${ }^{3} J_{\mathrm{HH}}$ obtained directly from ${ }^{1} \mathrm{H}$ NMR spectra ${ }^{16}$ and NOE values ${ }^{17}$ obtained from NOESY experiments (see the Supporting Information for details).

Curiously, compound $\mathbf{6 b}$ was not further reduced under high pressures of $\mathrm{H}_{2}$. Also, this compound shows a trans relationship between the hydrogen atoms at the 6-7 ring junction, and the other possible diastereomer (6a), which would have a cis relationship between these hydrogen atoms, was not observed. The hydrogenation of each individual double bond is expected to occur by cis addition of $\mathrm{H}_{2}$. However, it is intriguing that the second double bond hydrogenation occurs preferentially at the opposite face of the first hydrogenation step to furnish $\mathbf{6 b}$.

A plausible mechanistic rationale accounting for the formation of the products of this reaction is shown in Scheme 3.

Benzyl hydrogenolysis should occur quickly, even at low hydrogen pressure. ${ }^{18}$ Indeed, the disappearance of the typical aromatic protons of the benzyl group in the crude ${ }^{1} \mathrm{H}$ NMR spectrum was observed after only $1 \mathrm{~h}$ of reaction at $1 \mathrm{~atm}$ of $\mathrm{H}_{2}$ pressure. Debenzylated intermediate 10 could be hydrogenated in either one of the two double bonds of the 6-membered ring. Supposing that the double bond in the $\alpha$ position to the nitrogen atom is hydrogenated preferentially (C5-C6 reduction), there is formation of enol 11, which in turn can furnish compound $\mathbf{6 b}$ via keto-enol tautomerism. Catalytic hydrogenation of either $\mathbf{1 1}$ or 12, which would come from C7-C8 reduction, could then furnish alcohol 9. Since formation of the stereogenic center at position 7 occurs with protonation of $\mathbf{1 1}$, we sought to further study this step of the keto-enol equilibrium.

To elucidate the reason for the observed stereoselectivity of the hydrogenation step, theoretical calculations were carried out for compound 6 for both cis $(\mathbf{6 a})$ and trans $(6 \mathbf{b})$ relative stereochemistries (see the Supporting Information for details).

For both compounds $\mathbf{6 a}$ and $\mathbf{6 b}$, the conformer of type $\mathbf{I}$ is the most stable at the B3LYP-D3/aug-cc-pVDZ level in EtOAc. Its geometrical representations are shown in Figure 2 and considered for further comparative calculations between these two diastereomers using DFT functionals and $a b$ initio methods (Table S1, Supporting Information).

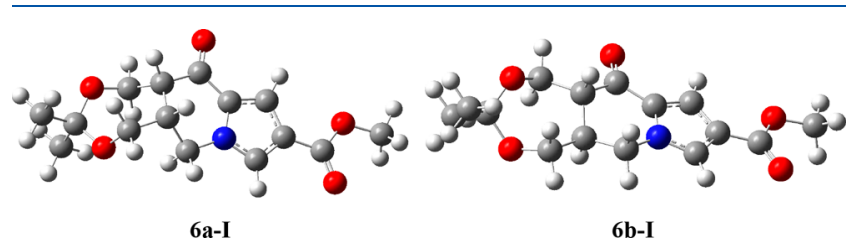

Figure 2. Geometrical representations for the global minima of 6a and $\mathbf{6 b}$ obtained at the B3LYP-D3/aug-cc-pVDZ level in EtOAC, using the IEF-PCM implicit solvent model.

The $a b$ initio methods show that electron correlation is an important factor to be taken into account, since the HF method shows the opposite result in comparison to MP2, Grimme's spin-component-scaled (SCS) ${ }^{19}$ MP2 and MP4 methods, which indicate that 6 a should be more stable than 6b. Similarly, the B3LYP functional shows the opposite result, indicating that $6 \mathrm{~b}$ should be $0.55 \mathrm{kcal} \cdot \mathrm{mol}^{-1}$ more stable than 6a ( $\Delta G$ values, Table $S 1$, Supporting Information). When Grimme's D3 dispersion correction ${ }^{19}$ is applied to the B3LYP method, 6a becomes more stable, hence indicating both electron correlation and dispersion corrections should be important parameters to account for the energy difference between $\mathbf{6 a}$ and $\mathbf{6 b}$.

Based on these results, we applied Truhlar's M06, M06-2X, and M11 functionals ${ }^{20,21}$ and Grimme's B2PLYP functional ${ }^{22}$ including D3 dispersion correction for the latter. These functionals showed a considerable increase in $\Delta G$ values favoring $\mathbf{6 a}$ in comparison to B3LYP-D3. By considering the calculated $\Delta G$ values for these functionals, the approximate ratio between $6 \mathbf{a}$ and $\mathbf{6 b}(\mathbf{6 a : 6 b})$ is calculated to be of $1: 1$ for B3LYP-D3, 2:1 for M06-2X, 3:1 for M06, 4:1 for M11, and 7:1 for B2PLYP-D3. Although these functionals show a higher stability for $\mathbf{6 a}$, they are not in complete agreement with the experimental result, since $\mathbf{6 a}$ was not observed in any proportion. The MP2 ab initio method shows a $6 \mathbf{a}: \mathbf{6 b}$ ratio of 10:1 (1.38 kcal.mol ${ }^{-1}$; Table S1, Supporting Information). However, the SCS-MP2, which is considered an improvement for the MP2 method, ${ }^{23}$ shows a smaller 5:1 ratio. Although of high accuracy, the SCS-MP2 approach cannot replace the $\operatorname{CCSD}(\mathrm{T})$ model, $^{24}$ which has been termed as "the gold standard" in the literature, ${ }^{25}$ mainly when applied together with the CBS approximation. ${ }^{26}$ The $\operatorname{CCSD}(\mathrm{T})$ method, which scales as $\mathrm{N}^{7}$ ( $\mathrm{N}=$ basis set), was shown to be prohibitively expensive to be applied for $\mathbf{6 a}$ and $\mathbf{6} \mathbf{b}$. However, we could apply the MP4(SDQ) method ${ }^{27}$ and the DLPNO-CCSDT(T)/aug-cc-pVTZ ${ }^{28-30}$ level, which may be considered the highest levels applied in this work. The MP4(SDQ) showed a Gibbs free energy preference for $6 \mathrm{a}$ of $1.82 \mathrm{kcal} \cdot \mathrm{mol}^{-1}$ (Table S1, Supporting Information). Such an energy difference would correspond to a ratio higher than 20:1. However, the DLPNO$\operatorname{CCSD}(\mathrm{T})$ showed only a slight preference for $6 \mathbf{a}$ of $0.19 \mathrm{kcal}$. $\mathrm{mol}^{-1}$, which increases to $0.82 \mathrm{kcal} \cdot \mathrm{mol}^{-1}$ when thermal Gibbs free energy corrections from the M11 functional are added. Thus, even high-level $a b$ initio methods diverge in the energy difference between $\mathbf{6 a}$ and $\mathbf{6 b}$, showing that $\mathbf{6 a}$ should be slightly more stable, even though it could not be observed experimentally. It is worth mentioning that keto-enol tautomerism has been shown to be a challenge for high level $a b$ initio methods and DFT calculations in the gas phase and implicit solvent even for simpler molecular systems in previous benchmark studies. ${ }^{31}$

Thus, although the cis isomer should be the most stable, the keto-enol tautomerism can have a high barrier in this molecular system, with the formation of the trans isomer controlled kinetically instead of thermodynamically. Indeed, it was observed that carboxylic acids can catalyze the keto-enol tautomerism and decrease the Gibbs free energy barrier of keto-enol interconversion by as much as $45 \mathrm{kcal} \cdot \mathrm{mol}^{-1}$. $32-34$ Because the reaction in this work is being carried out in EtOAc, some residual acetic acid $(\mathrm{AcOH})$ may be present in the reaction mixture, catalyzing the reaction, decreasing the barrier height, and possibly making $\mathbf{6} \mathbf{b}$ the favored kinetic product.

The keto tautomer (6a or $\mathbf{6 b}$, see the Supporting Information) is more stable than the enol tautomer (11) by as much as $19 \mathrm{kcal} \cdot \mathrm{mol}^{-1}$ (M11/aug-cc-pVDZ), and the uncatalyzed energy barrier in the stepwise mechanism can be as high as $\sim 50-60 \mathrm{kcal} \cdot \mathrm{mol}^{-1} \cdot{ }^{32-34}$ In order to evaluate the kinetic product, we obtained the reaction barriers for formation of $\mathbf{6 a}$ and $\mathbf{6 b}$ from 11 catalyzed by AcOH (Figure 3). These calculations were carried out at the M11/aug-cc-pVDZ level, since this theoretical level showed similar results to the 


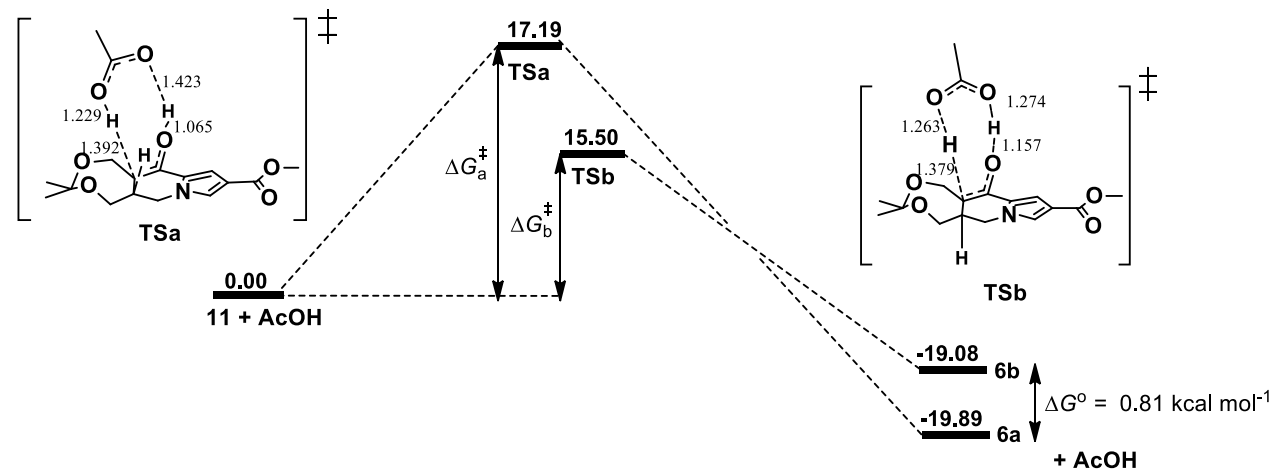

Figure 3. Energy diagram and transition state geometrical representations for the keto-enol tautomerization step for formation of 6 a through TSa and $\mathbf{6 b}$ through $\mathbf{T S b}$ calculated at the M11/aug-cc-pVDZ level. The energies are given in $\mathrm{kcal} \cdot \mathrm{mol}^{-1}$. Forming/breaking $\mathrm{C}=\mathrm{O} \cdots \mathrm{H} \cdots \mathrm{O}$ and $\mathrm{C}=$ $\mathrm{O} \cdots \mathrm{H} \cdots \mathrm{C}$ bond distances are showed in angstroms.

DLPNO-CCSD $(\mathrm{T}) /$ aug-cc-pVTZ (Table S1, Supporting Information). Such calculations showed a $\Delta G^{\ddagger}$ value of $15.50 \mathrm{kcal} \cdot \mathrm{mol}^{-1}$ for $\mathbf{6 b}$ and $17.19 \mathrm{kcal} \cdot \mathrm{mol}^{-1}$ for $\mathbf{6 a}$; hence, the barrier for $\mathbf{6 a}$ is $1.69 \mathrm{kcal} \cdot \mathrm{mol}^{-1}$ higher than that for $\mathbf{6 b}$. Thus, $\mathbf{6} \mathbf{b}$ is the kinetic product and $\mathbf{6 a}$ is the thermodynamic one. Because $\mathbf{6 a}$ is not observed experimentally, these results suggest that the observed product $\mathbf{6} \mathbf{b}$ may be preferentially formed under kinetic control. Quantitatively, our computed difference in the activation barriers is probably somewhat underestimated, because it would correspond to a $\mathbf{6 a}: \mathbf{6 b}$ distribution of 5:95 at room temperature. Qualitatively, however, our results provide evidence for this reaction being under kinetic control, and this may be the reason why the diastereomer with cis stereochemistry is not observed experimentally.

The present work explored the heterogeneous hydrogenation of a polyfunctionalized indolizine (5), which was prepared by using a straightforward two-step sequence based on a Morita-Baylis-Hillman reaction with a known pyridine2 -carboxaldehyde. The partial hydrogenation step was shown to be highly diastereoselective, forming trans ketone $6 \mathrm{~b}$ in $30 \%$ yield and cis alcohol 9 as an inseparable mixture of unassigned compounds. The intriguing experimental preference of trans diastereomer $\mathbf{6 b}$ was unveiled by applying high level $a b$ initio and DFT theoretical calculations, which pointed out the establishment of a keto-enol tautomerism as the key step of the hydrogenation reaction. Under the experimental conditions, the kinetic (trans, $\mathbf{6 b}$ ) isomer is favored in detriment of the thermodynamic (cis, 6a) isomer. The transition state for the trans isomer is more stable by $1.69 \mathrm{kcal} \cdot \mathrm{mol}^{-1}$ in comparison to the cis isomer. Lastly, the present work may help guide future experiments for the exploration of keto-enol tautomerism to efficiently select thermodynamic/kinetic diastereomers in heterogeneous hydrogenation reactions.

\section{EXPERIMENTAL SECTION}

General Procedures. All chemicals and solvents were of analytical grade, purchased from commercial sources, and used without further purification unless otherwise stipulated.

Unless otherwise noted, all reactions were performed under an ambient atmosphere in oven-dried open-flask glassware with magnetic stirring. Reaction progress was monitored by analytical thin-layer chromatography (TLC) performed on precoated silica gel 60 F254 (5-40 $\mu \mathrm{m}$ thickness) plates. The TLC plates were visualized with UV light $(254 \mathrm{~nm})$ and/or potassium permanganate or sulfuric vanillin followed by heating. When necessary, reaction products were purified by flash column chromatography using silica gel (230-400 mesh).
Nuclear magnetic resonance spectra were recorded in deuterated solvents at room temperature at 250,400,500, and $600 \mathrm{MHz}$. Data are reported as follows: chemical shift $(\delta)$ in ppm, multiplicity, coupling constant $(J)$, and integrated intensity. Abbreviations to denote the multiplicity of a particular signal are s (singlet), bs (broad singlet), d (doublet), $\mathrm{t}$ (triplet), dd (double doublet), ddd (double double doublet), dddd (double double double doublet), ddddd (double double double double doublet), and m (multiplet).

The high-resolution mass spectrometric analyses (HRMS) were performed in a Q-TOF instrument, equipped with ESI ionization source operating in the positive mode (ESI(+)-MS). The samples were injected by direct infusion in a $40 \mu \mathrm{L} \cdot \mathrm{min}^{-1}$ flow. The following parameters were used: $3 \mathrm{kV}$ capillary voltage, $20 \mathrm{~V}$ cone voltage, source temperature of $120^{\circ} \mathrm{C}$, and nebulization gas flow of $0.5 \mathrm{~L} \cdot \mathrm{h}^{-1}$. Before every analysis, the instrument was calibrated with an $\mathrm{H}_{3} \mathrm{PO}_{4}$ solution $\left(0.005 \%\right.$ in $\left.\mathrm{H}_{2} \mathrm{O} / \mathrm{CH}_{3} \mathrm{CN} 1: 1\right)$ from $\mathrm{m} / z 100$ to 1000 .

Hydrogenation reactions were carried out in a suitable reactor fitted with a mechanic stirrer and a system for measuring and controlling both pressure and temperature (Parr Instruments Series 4590 Micro Stirred Reactor).

Reactions under ultrasound were carried out in an ultrasonic cleaner UNIQUE model GA 1000 (1000 W, $25 \mathrm{kHz})$.

Compounds were named according to IUPAC rules using the MarvinSketch 20.11 software. Compounds S1-S5 are the intermediates for the preparation of aldehyde 7 .

Preparation of Compound S1. [5-(Benzyloxy)-4-(hydroxymethyl)-6-methylpyridin-3-yl]methanol (S1). ${ }^{13}$ To a round-bottomed flask containing pyridoxine hydrochloride $(2.00 \mathrm{~g}, 9.73$ $\mathrm{mmol}$ ) and anhydrous potassium carbonate (3.0 equiv, $4.03 \mathrm{~g}, 29.2$ $\mathrm{mmol})$ was added anhydrous acetonitrile $(160 \mathrm{~mL})$ under stirring. The mixture was heated to reflux using a preheated silicone oil bath (at $\sim 90{ }^{\circ} \mathrm{C}$ ) for $1 \mathrm{~h}$. Then, benzyl bromide (1.0 equiv, $1.16 \mathrm{~mL}, 9.73$ $\mathrm{mmol}$ ) was added and the reaction mixture was stirred under reflux for $3 \mathrm{~h}$. After this time, the reaction was allowed to cool to room temperature and then was quenched by addition of distilled water $(100 \mathrm{~mL})$. The mixture was extracted with EtOAc $(4 \times 30 \mathrm{~mL})$, and the combined organic phases were dried with anhydrous $\mathrm{Na}_{2} \mathrm{SO}_{4}$, filtered, and concentrated under reduced pressure. The resulting solid was recrystallized from $\mathrm{EtOH}$ to afford the desired product as a brown crystalline solid in $83 \%$ yield $(2.09 \mathrm{~g}, 8.06 \mathrm{mmol}) . \mathrm{Mp}=111-113{ }^{\circ} \mathrm{C}$ (lit. $\left.{ }^{13} 113-114{ }^{\circ} \mathrm{C}\right) .{ }^{1} \mathrm{H}$ NMR $\left(250 \mathrm{MHz}\right.$, DMSO- $\left.d_{6}\right): \delta 8.27(\mathrm{~s}, 1 \mathrm{H})$, $7.54-7.33(\mathrm{~m}, 5 \mathrm{H}), 5.25(\mathrm{t}, J=5.5 \mathrm{~Hz}, 1 \mathrm{H}, \mathrm{OH}), 5.15(\mathrm{t}, J=5.5 \mathrm{~Hz}$ $1 \mathrm{H}, \mathrm{OH}), 4.89(\mathrm{~s}, 2 \mathrm{H}), 4.67(\mathrm{~d}, J=5.5 \mathrm{~Hz}, 2 \mathrm{H}), 4.60(\mathrm{~d}, J=5.5 \mathrm{~Hz}$, $2 \mathrm{H}), 2.42(\mathrm{~s}, 3 \mathrm{H}) .{ }^{13} \mathrm{C}\left\{{ }^{1} \mathrm{H}\right\}$ NMR $\left(62.9 \mathrm{MHz}\right.$, DMSO-d $\left.d_{6}\right): \delta 151.2$, $150.7,143.7,139.7,137.0,135.4,128.5$ (2C), 128.19 (2C), 128.18, 75.8, 58.6, 53.9, 19.4. HRMS (ESI/Q-TOF) $m / z$ : Calcd for $\mathrm{C}_{15} \mathrm{H}_{18} \mathrm{NO}_{3}[\mathrm{M}+\mathrm{H}]^{+}$260.1281, found 260.1281 .

Preparation of Indolizine 5. 9-(Benzyloxy)-3,3,8-trimethyl$1 \mathrm{H}, 3 \mathrm{H}, 5 \mathrm{H}$-[1,3]dioxepino[5,6-c]pyridine (S2). ${ }^{13}$ To a round-bottomed flask, S1 (3.41 g, $13.2 \mathrm{mmol}$ ) and 2,2-dimethoxypropane $(180 \mathrm{~mL})$ were added. The mixture was then heated to reflux using a 
preheated silicone oil bath (at $\sim 90{ }^{\circ} \mathrm{C}$ ) until complete dissolution of the starting material. Then, $p$-toluenesulfonic acid monohydrate $(0.05$ equiv, $125.1 \mathrm{mg}, 0.658 \mathrm{mmol}$ ) was added to the solution under stirring, and the reaction mixture was maintained under these conditions for $14 \mathrm{~h}$. After this time, the reaction mixture was allowed to cool to room temperature and then quenched by adding distilled $\mathrm{H}_{2} \mathrm{O}(50 \mathrm{~mL})$ and $\mathrm{NaHSO}_{4} \cdot \mathrm{H}_{2} \mathrm{O}(75 \mathrm{mg})$. The resulting mixture was extracted with $\mathrm{CH}_{2} \mathrm{Cl}_{2}(4 \times 50 \mathrm{~mL})$, and the combined organic phases were dried with anhydrous $\mathrm{Na}_{2} \mathrm{SO}_{4}$, filtered, and concentrated under reduced pressure to furnish crude seven-membered cyclic acetal as a viscous brown oil in quantitative yield $(4.14 \mathrm{~g})$. This compound was sufficiently pure to be used in the next step without further purification. ${ }^{1} \mathrm{H}$ NMR $\left(400 \mathrm{MHz}, \mathrm{CDCl}_{3}\right): \delta 8.03(\mathrm{~s}, 1 \mathrm{H}), 7.47-7.34$ $(\mathrm{m}, 5 \mathrm{H}), 4.82(\mathrm{~s}, 2 \mathrm{H}), 4.81-4.77(\mathrm{~m}, 4 \mathrm{H}), 2.51(\mathrm{~s}, 3 \mathrm{H}), 1.45(\mathrm{~s}, 6 \mathrm{H})$. ${ }^{13} \mathrm{C}\left\{{ }^{1} \mathrm{H}\right\}$ NMR $\left(101 \mathrm{MHz}, \mathrm{CDCl}_{3}\right): \delta 151.1,150.1,141.8,141.2$, 136.4, 133.7, 128.9 (2C), 128.7, 128.2 (2C), 102.8, 75.4, 61.8, 59.4, 23.8, 19.1. HRMS (ESI/Q-TOF) $\mathrm{m} / z$ : Calcd for $\mathrm{C}_{18} \mathrm{H}_{22} \mathrm{NO}_{3}[\mathrm{M}+$ $\mathrm{H}]^{+}$300.1594, found 300.1593 .

9-(Benzyloxy)-3,3,8-trimethyl-1H,3H,5H-[1,3]dioxepino[5,6-c]pyridin-7-ium-7-olate (S3). ${ }^{13} \mathrm{mCPBA}$ (purity $\leq 77 \%$ ) (1.6 equiv, $4.82 \mathrm{~g}, 21.5 \mathrm{mmol}$ ) was carefully added to a solution of $\mathbf{S 2}$ (4.03 g; $13.4 \mathrm{mmol})$ in $\mathrm{CHCl}_{3}(100 \mathrm{~mL})$, and the reaction mixture was stirred for $14 \mathrm{~h}$ at room temperature in the dark. After this time, the reaction was quenched by addition of $10 \%(\mathrm{~m} / \mathrm{v})$ aqueous solution of $\mathrm{NaHSO}_{4}(90 \mathrm{~mL})$. The phases were separated, and the organic phase was washed with $10 \%(\mathrm{~m} / \mathrm{v})$ aqueous solution of $\mathrm{NaHSO}_{4}(2 \times 90$ $\mathrm{mL}), 10 \%(\mathrm{~m} / \mathrm{v})$ aqueous solution of $\mathrm{NaHCO}_{3}(2 \times 90 \mathrm{~mL})$, and distilled $\mathrm{H}_{2} \mathrm{O}(90 \mathrm{~mL})$. The organic phase was dried with anhydrous $\mathrm{NaSO}_{4}$, filtered, and concentrated under reduced pressure to give the desired $\mathrm{N}$-oxide as a viscous yellow oil in quantitative yield $(4.25 \mathrm{~g})$. This compound was sufficiently pure to be used in the next step without further purification. ${ }^{1} \mathrm{H} \mathrm{NMR}\left(400 \mathrm{MHz}, \mathrm{CDCl}_{3}\right): \delta 7.95$ (s, $1 \mathrm{H}), 7.45-7.33(\mathrm{~m}, 5 \mathrm{H}), 4.81(\mathrm{~s}, 2 \mathrm{H}), 4.74-4.66(\mathrm{~m}, 4 \mathrm{H}), 2.45(\mathrm{~s}$, $3 \mathrm{H}), 1.43(\mathrm{~s}, 6 \mathrm{H}) .{ }^{13} \mathrm{C}\left\{{ }^{1} \mathrm{H}\right\}$ NMR $\left(101 \mathrm{MHz}, \mathrm{CDCl}_{3}\right): \delta$ 151.6, 143.2 , 135.5, 134.7, 133.1, 132.3, 129.02, 128.96 (2C), 128.4 (2C), 103.0, 76.5, 61.4, 59.1, 23.6, 11.8. HRMS (ESI/Q-TOF) $\mathrm{m} / z$ : Calcd for $\mathrm{C}_{18} \mathrm{H}_{22} \mathrm{NO}_{4}[\mathrm{M}+\mathrm{H}]^{+} 316.1543$, found 316.1543 .

[9-(Benzyloxy)-3,3-dimethyl-1H,3H,5H-[1,3]dioxepino[5,6-c]pyridin-8-yl]methyl Acetate (S4). In a round-bottomed flask, S3 (4.15 g; $13.1 \mathrm{mmol})$ was dissolved in anhydrous acetic anhydride (66 $\mathrm{mL}, 0.20 \mathrm{~mol} \cdot \mathrm{L}^{-1}$ ) under stirring at room temperature and heated to $70{ }^{\circ} \mathrm{C}$ using a preheated silicone-oil bath for $1 \mathrm{~h}$. [CAUTION: This transformation, also known as the Boekelheide reaction, may proceed rather exothermically and vigorously. A reflux condenser should be adapted to the flask.] Then, the reaction mixture was allowed to reach room temperature and distilled water $(160 \mathrm{~mL})$ was slowly added to the flask. The resulting mixture was extracted with EtOAc $(3 \times 50$ $\mathrm{mL}$ ), and the combined organic phases were dried with anhydrous $\mathrm{Na}_{2} \mathrm{SO}_{4}$, filtered, and concentrated under reduced pressure to furnish crude acetate as a viscous yellow oil in quantitative yield $(5.03 \mathrm{~g})$. This compound was sufficiently pure to be used in the next step without further purification. ${ }^{1} \mathrm{H}$ NMR $\left(500 \mathrm{MHz}, \mathrm{CDCl}_{3}\right): \delta 8.13$ (s, $1 \mathrm{H}), 7.42-7.33(\mathrm{~m}, 5 \mathrm{H}), 5.19(\mathrm{~s}, 2 \mathrm{H}), 4.85(\mathrm{~s}, 2 \mathrm{H}), 4.81(\mathrm{~s}, 4 \mathrm{H})$, $2.06(\mathrm{~s}, 3 \mathrm{H}), 1.44(\mathrm{~s}, 6 \mathrm{H}) \cdot{ }^{13} \mathrm{C}\left\{{ }^{1} \mathrm{H}\right\} \mathrm{NMR}\left(126 \mathrm{MHz}, \mathrm{CDCl}_{3}\right): \delta$ $170.7,150.5,147.7,142.7,141.8,136.0,135.9,128.8$ (2C), 128.7, 128.2 (2C), 102.8, 76.9, 62.4, 61.7, 58.9, 23.6, 20.9. HRMS (ESI/QTOF) $\mathrm{m} / z$ : Calcd for $\mathrm{C}_{20} \mathrm{H}_{24} \mathrm{NO}_{5}[\mathrm{M}+\mathrm{H}]^{+} 358.1649$, found 358.1647.

[9-(Benzyloxy)-3,3-dimethyl-1H,3H,5H-[1,3]dioxepino[5,6-c]pyridin-8-yl]methanol (S5). ${ }^{13} \mathrm{NaH}$ (60\% dispersion in mineral oil) (1.8 equiv, $587 \mathrm{mg} ; 24.4 \mathrm{mmol}$ ) was weighted in a flame-dried roundbottomed flask under a nitrogen atmosphere, carefully dissolved in 80 $\mathrm{mL}$ of dry methanol at $-10{ }^{\circ} \mathrm{C}$ (ethylene glycol/dry $\mathrm{CO}_{2}$ cryogenic bath), and left to stir for $45 \mathrm{~min}$. This solution was transferred via cannula to a solution of $\mathbf{S} 4(4.86 \mathrm{~g}, 13.6 \mathrm{mmol})$ in $50 \mathrm{~mL}$ of $\mathrm{CHCl}_{3}$ at $0{ }^{\circ} \mathrm{C}$ and under stirring. The reaction mixture was left to warm to room temperature $(30 \mathrm{~min})$ and then stirred for $2 \mathrm{~h}$. After this time, the reaction was quenched with saturated aqueous solution of $\mathrm{NH}_{4} \mathrm{Cl}$ $(50 \mathrm{~mL})$, and the resulting mixture was extracted with EtOAc $(4 \times 50$ $\mathrm{mL})$. The combined organic phases were dried with anhydrous
$\mathrm{Na}_{2} \mathrm{SO}_{4}$, filtered, and concentrated under reduced pressure to afford crude primary alcohol as a light brown solid in 93\% yield (3.98 g, 12.6 $\mathrm{mmol}$ ). This compound was sufficiently pure to be used in the next step without further purification. $\mathrm{Mp}=140-142{ }^{\circ} \mathrm{C}\left(\right.$ lit. $\left.{ }^{13} 144^{\circ} \mathrm{C}\right)$. ${ }^{1} \mathrm{H}$ NMR (500 MHz, $\left.\mathrm{CDCl}_{3}\right): \delta 8.09(\mathrm{~s}, 1 \mathrm{H}), 7.58-7.30(\mathrm{~m}, 5 \mathrm{H})$, 4.95-4.78 (m, 6H), $4.74(\mathrm{~s}, 2 \mathrm{H}), 4.46(\mathrm{bs}, 1 \mathrm{H}, \mathrm{OH}), 1.47(\mathrm{~s}, 6 \mathrm{H})$. ${ }^{13} \mathrm{C}\left\{{ }^{1} \mathrm{H}\right\}$ NMR $\left(126 \mathrm{MHz}, \mathrm{CDCl}_{3}\right): \delta 151.3,148.7,141.34,141.32$, 136.0, 134.8, 128.8 (2C), 128.7, 128.2 (2C), 102.8, 76.2, 61.7, 60.1, 59.0, 23.6. HRMS (ESI/Q-TOF) $m / z$ : Calcd for $\mathrm{C}_{18} \mathrm{H}_{22} \mathrm{NO}_{4}[\mathrm{M}+$ $\mathrm{H}]^{+}$316.1543, found 316.1543.

9-(Benzyloxy)-3,3-dimethyl-1H,3H,5H-[1,3]dioxepino[5,6-c]pyridine-8-carbaldehyde (7). ${ }^{13}$ A solution of $\mathbf{S 5}(1.07 \mathrm{~g}, 3.38 \mathrm{mmol}$ ) in anhydrous $\mathrm{CH}_{2} \mathrm{Cl}_{2}(70 \mathrm{~mL})$ was prepared in a round-bottomed flask. The solution was cooled to $0{ }^{\circ} \mathrm{C}$, and then, trichloroisocyanuric acid (1.0 equiv, $785 \mathrm{mg}, 3.38 \mathrm{mmol}$ ) and TEMPO (0.01 equiv, 5.3 $\mathrm{mg}, 0.338 \mathrm{mmol}$ ) were carefully added to the reaction mixture under stirring. A change in the color of the reaction mixture was noticed within the first $5 \mathrm{~min}$ of reaction time (it became an orange suspension). After $30 \mathrm{~min}$, the mixture was filtered through a plug of Celite, and the filtrate was concentrated under reduced pressure, affording aldehyde 7 as a viscous yellow oil in quantitative yield (1.13 g). This compound was sufficiently pure to be used in the next step without further purification. ${ }^{1} \mathrm{H}$ NMR $\left(400 \mathrm{MHz}, \mathrm{CDCl}_{3}\right): \delta 10.15$ (s, $1 \mathrm{H}), 8.29(\mathrm{~s}, 1 \mathrm{H}), 7.45-7.34(\mathrm{~m}, 5 \mathrm{H}), 5.01(\mathrm{~s}, 2 \mathrm{H}), 4.88(\mathrm{~s}, 2 \mathrm{H})$, $4.78(\mathrm{~s}, 2 \mathrm{H}), 1.44(\mathrm{~s}, 6 \mathrm{H}) \cdot{ }^{13} \mathrm{C}\left\{{ }^{1} \mathrm{H}\right\}$ NMR $\left(101 \mathrm{MHz}, \mathrm{CDCl}_{3}\right): \delta$ $191.1,153.7,144.1,143.6,143.5,140.6,135.9,129.0,128.9$ (4C), 103.0, 78.2, 61.9, 59.0, 23.6. HRMS (ESI/Q-TOF) $\mathrm{m} / \mathrm{z}$ : Calcd for $\mathrm{C}_{18} \mathrm{H}_{20} \mathrm{NO}_{4}[\mathrm{M}+\mathrm{H}]^{+}$314.1387, found 314.1384.

Methyl 2-\{[9-(Benzyloxy)-3,3-dimethyl-1H,3H,5H-[1,3]dioxepino[5,6-c]pyridin-8-yl](hydroxy)methyl\}prop-2-enoate (8). Aldehyde 7 $(1.47 \mathrm{~g}, 4.91 \mathrm{mmol})$ and 1,4-diazabicyclo[2.2.2] octane (DABCO, 0.65 equiv, $342 \mathrm{mg}, 3.05 \mathrm{mmol}$ ) were added to a $250 \mathrm{~mL}$ roundbottomed flask. Then, methyl acrylate (20 equiv, $8.5 \mathrm{~mL}, 93.8 \mathrm{mmol}$ ) was added to the reaction mixture without magnetic stirring, and the reaction flask was fitted with a rubber septum and connected with a gas bubbler (with silicone oil). [CAUTION: methyl acrylate has a pungent odor and lachrymatory properties: its manipulation must be carried out in a well-ventilated fume hood.] The reaction mixture is sonicated in an ultrasound bath for $64 \mathrm{~h}$ (the water bath in the ultrasound equipment was kept at room temperature). After this time, the excess methyl acrylate was removed under reduced pressure (alternatively, excess methyl acrylate can be recovered via distillation). The crude product was redissolved in EtOAc $(40 \mathrm{~mL})$, and the solution was washed with saturated aqueous solution of $\mathrm{NH}_{4} \mathrm{Cl}(4 \times$ $20 \mathrm{~mL}$ ). The organic phase was dried with anhydrous $\mathrm{Na}_{2} \mathrm{SO}_{4}$ and filtered, and the solvent was removed under reduced pressure to afford crude $\mathrm{MBH}$ adduct 8 as a yellow oil in $85 \%$ yield (1.66 g, 4.17 $\mathrm{mmol})$. Compound $\mathbf{8}$ was sufficiently pure to be used in the next step without further purification. ${ }^{1} \mathrm{H}$ NMR $\left(250 \mathrm{MHz}, \mathrm{CDCl}_{3}\right): \delta 8.10(\mathrm{~s}$, $1 \mathrm{H}), 7.42-7.35(\mathrm{~m}, 5 \mathrm{H}), 6.28(\mathrm{~s}, 1 \mathrm{H}), 5.85(\mathrm{~s}, 1 \mathrm{H}), 5.61(\mathrm{~s}, 1 \mathrm{H})$, $4.96-4.70(\mathrm{~m}, 6 \mathrm{H}), 3.67(\mathrm{~s}, 3 \mathrm{H}), 1.47(\mathrm{~s}, 3 \mathrm{H}), 1.46(\mathrm{~s}, 3 \mathrm{H}) .{ }^{13} \mathrm{C}\left\{{ }^{1} \mathrm{H}\right\}$ NMR $\left(63 \mathrm{MHz}, \mathrm{CDCl}_{3}\right): \delta 166.7,152.1,149.3,142.2,142.0,141.5$, 136.3, 135.7, 128.9 (2C), 128.8, 128.3 (2C), 126.7, 103.0, 76.5, 67.8, $62,0,59.2,52.1,23.8$. HRMS (ESI/Q-TOF) $\mathrm{m} / z$ : Calcd for $\mathrm{C}_{22} \mathrm{H}_{26} \mathrm{NO}_{6}[\mathrm{M}+\mathrm{H}]^{+}$400.1755, found 400.1740 .

Methyl 11-(Benzyloxy)-3,3-dimethyl-1H,3H,5H-[1,3]dioxepino[5,6-f]indolizine-9-carboxylate (5). $\mathrm{MBH}$ adduct 8 (1.43 g, 3.57 $\mathrm{mmol})$ was dissolved in acetic anhydride $\left(21.0 \mathrm{~mL}, 0.17 \cdot \mathrm{mol} \mathrm{L}^{-1}\right)$ and heated at $100{ }^{\circ} \mathrm{C}$ (silicone oil bath) for $19 \mathrm{~h}$ under stirring. When the reaction was considered finished by TLC, it was allowed to reach room temperature and then carefully quenched by addition of distilled $\mathrm{H}_{2} \mathrm{O}(250 \mathrm{~mL})$. The resulting mixture was extracted with EtOAc $(3 \times$ $50 \mathrm{~mL}$ ). The combined organic phases were dried with anhydrous $\mathrm{Na}_{2} \mathrm{SO}_{4}$, filtered, and concentrated under reduced pressure. The crude product was purified by column chromatography (silica gel, EtOAc/ hexane $20: 80$ ) to afford substituted indolizine 5 as a brown oil in $65 \%$ yield $(0.883 \mathrm{~g}, 2.32 \mathrm{mmol}) .{ }^{1} \mathrm{H}$ NMR $\left(250 \mathrm{MHz}, \mathrm{CDCl}_{3}\right): \delta 7.74(\mathrm{~d}, J$ $=1.5 \mathrm{~Hz}, 1 \mathrm{H}), 7.49(\mathrm{~s}, 1 \mathrm{H}), 7.48-7.32(\mathrm{~m}, 5 \mathrm{H}), 6.90(\mathrm{~s}, 1 \mathrm{H}), 5.14$ (s, $2 \mathrm{H}), 4.76(\mathrm{~s}, 2 \mathrm{H}), 4.67(\mathrm{~s}, 2 \mathrm{H}), 3.88(\mathrm{~s}, 3 \mathrm{H}), 1.43(\mathrm{~s}, 6 \mathrm{H})$. ${ }^{13} \mathrm{C}\left\{{ }^{1} \mathrm{H}\right\}$ NMR $\left(63 \mathrm{MHz}, \mathrm{CDCl}_{3}\right): \delta 165.6,145.7,136.9,128.9$ (2C), 
128.6, 128.47 (2C), 128.45, 125.5, 120.5, 119.8, 117.9, 116.8, 102.7, 98.8, 74.8, 62.0, 59.1, 51.7, 24.1. HRMS (ESI/Q-TOF) $\mathrm{m} / z$ : Calcd for $\mathrm{C}_{22} \mathrm{H}_{24} \mathrm{NO}_{5}[\mathrm{M}+\mathrm{H}]^{+}$382.1649, found 382.1679.

Heterogeneous Hydrogenation of Indolizine 5. Indolizine 5 (120 mg, $0.315 \mathrm{mmol}$ ) was dissolved in ethyl acetate $(5 \mathrm{~mL}), \mathrm{Rh} /$ $\mathrm{Al}_{2} \mathrm{O}_{3}(12 \mathrm{mg}, 10 \% \mathrm{w} / \mathrm{w})$ was added to the solution, and the atmosphere was replaced with $\mathrm{H}_{2}$ (80 bar) in a hydrogenation reactor. The reaction mixture was stirred vigorously for $48 \mathrm{~h}$ at room temperature. Then, the reaction medium was purged with $\mathrm{N}_{2}$ and filtered through a plug of Celite, and the filtrate was concentrated. Analysis of the crude by ${ }^{1} \mathrm{H}$ NMR showed three main products, which were purified by column chromatography (silica gel, EtOAc/hexane $30: 70)$ to afford product $\mathbf{6 b}(27 \mathrm{mg}, 0.094 \mathrm{mmol})$ in $30 \%$ yield as a colorless oil and a mixture containing $9(27 \mathrm{mg}, 0.091 \mathrm{mmol})$ as an oil.

Methyl (5aRS, 11aSR)-3,3-Dimethyl-11-oxo-1H,3H,5H,5aH,6H,11$\mathrm{H}, 11 \mathrm{aH}-[1,3]$ dioxepino[5,6-f]indolizine-9-carboxylate (6b). ${ }^{1} \mathrm{H}$ NMR $\left(600 \mathrm{MHz}, \mathrm{C}_{6} \mathrm{D}_{6}\right): \delta 7.71(\mathrm{~d}, J=1.7 \mathrm{~Hz}, 1 \mathrm{H}), 6.94(\mathrm{~d}, J=$ $1.7 \mathrm{~Hz}, 1 \mathrm{H}), 4.59$ (dd, $J=12.7,3.5 \mathrm{~Hz}, 1 \mathrm{H}), 3.71(\mathrm{dd}, J=12.7,9.8$ $\mathrm{Hz}, 1 \mathrm{H}), 3.55(\mathrm{~s}, 3 \mathrm{H}), 3.14(\mathrm{dd}, J=11.8,10.1 \mathrm{~Hz}, 1 \mathrm{H}), 2.92(\mathrm{dd}, J=$ $11.8,3.1 \mathrm{~Hz}, 1 \mathrm{H}), 2.65(\mathrm{dd}, J=12.3,4.2 \mathrm{~Hz}, 1 \mathrm{H}), 2.36(\mathrm{t}, J=12.3$ $\mathrm{Hz}, 1 \mathrm{H}), 1.88$ (ddd, $J=12.3,9.8,3.5 \mathrm{~Hz}, 1 \mathrm{H}), 1.56$ (tddd, $J=12.3$, 10.1, 4.2, $3.1 \mathrm{~Hz}, 1 \mathrm{H}), 1.23(\mathrm{~s}, 3 \mathrm{H}), 1.21(\mathrm{~s}, 3 \mathrm{H}) .{ }^{13} \mathrm{C}\left\{{ }^{1} \mathrm{H}\right\}$ NMR $\left(126 \mathrm{MHz}, \mathrm{C}_{6} \mathrm{D}_{6}\right): \delta 186.0,164.2,130.9,128.5,118.2,114.2,101.6$, $62.3,60.9,52.6,51.0,46.7,42.2,25.0,24.8$. HRMS (ESI/Q-TOF) $\mathrm{m} /$ $z$ : Calcd for $\mathrm{C}_{12} \mathrm{H}_{15} \mathrm{NaNO}_{5}$ (acetal deprotection) $[\mathrm{M}+\mathrm{Na}]^{+}$ 276.0842, found 276.0829.

Methyl (5aSR,11RS,11aSR)-11-Hydroxy-3,3-dimethyl$1 \mathrm{H}, 3 \mathrm{H}, 5 \mathrm{H}, 5 \mathrm{aH}, 6 \mathrm{H}, 11 \mathrm{H}, 11 \mathrm{aH}-[1,3]$ dioxepino[5,6-f]indolizine-9-carboxylate (9)-Present in a Mixture of Compounds (Only the signals of 9 Were Assigned; See the Supporting Information for Details). ${ }^{1} \mathrm{H}$ NMR (400 MHz, $\left.\mathrm{C}_{6} \mathrm{D}_{6}\right): \delta 7.20(\mathrm{~d}, J=1.8 \mathrm{~Hz}, 1 \mathrm{H})$, $7.07-7.05(\mathrm{~m}, 1 \mathrm{H}), 4.17(\mathrm{dd}, J=6.0,1.3 \mathrm{~Hz}, 1 \mathrm{H}), 3.94(\mathrm{dd}, J=13.0$, $11.5 \mathrm{~Hz}, 1 \mathrm{H}), 3.83$ (ddd, $J=12.7,3.0,1.3 \mathrm{~Hz}, 1 \mathrm{H}), 3.62(\mathrm{~s}, 2 \mathrm{H}), 3.53$ (dd, $J=12.6,1.7 \mathrm{~Hz}, 1 \mathrm{H}), 3.38(\mathrm{dd}, J=12.6,10.6 \mathrm{~Hz}, 1 \mathrm{H}), 3.13-$ $3.02(\mathrm{~m}, 2 \mathrm{H}), 2.17$ (dddd, $J=10.5,6.1,3.9,3.0 \mathrm{~Hz}, 1 \mathrm{H}), 1.42-1.35$ $(\mathrm{m}, 1 \mathrm{H}), 1.26(\mathrm{~s}, 3 \mathrm{H}), 1.09(\mathrm{~s}, 3 \mathrm{H}) .{ }^{13} \mathrm{C}\left\{{ }^{1} \mathrm{H}\right\}$ NMR $(101 \mathrm{MHz}$, $\left.\mathrm{C}_{6} \mathrm{D}_{6}\right): \delta 165.5,131.2,125.1,117.6,107.3,102.0,74.1,62.8,58.2$, 51.0, 43.1, 42.6, 36.2, 25.4, 25.3. HRMS (ESI/Q-TOF) $\mathrm{m} / z$ : Calcd for $\mathrm{C}_{15} \mathrm{H}_{22} \mathrm{NO}_{5}[\mathrm{M}+\mathrm{H}]^{+}$296.1492, found 296.1487.

Computational Details. Conformers of compounds $\mathbf{6 a}$ and $\mathbf{6 b}$ were located through a Monte Carlo conformational search at the MMFF level with the Spartan 14 program, ${ }^{35}$ using a $10 \mathrm{kcal} \cdot \mathrm{mol}^{-1}$ threshold and $5000 \mathrm{~K}$ initial temperature in the simulated-annealing algorithm. Optimizations and frequency calculations were carried out at the B3LYP-D3/aug-cc-pVDZ level using the Gaussian 09 program, revision D.01, ${ }^{36}$ for all conformers found in the Monte Carlo calculations. The lack of negative harmonic vibrational frequencies confirmed that all conformers are true energy minima, or the observation of a single negative frequency was used to characterize the geometry as a transition state. The same frequency calculations were used to evaluate thermodynamic corrections affording enthalpies and Gibbs free energies at ambient, standard temperature and pressure for each species. Solvent effects were evaluated by optimizing each conformer using an implicit solvent model, namely, the IEF-PCM (integral equation formalism variant of the polarizable continuum model).$^{37}$ The global minima of $\mathbf{6 a}$ and $\mathbf{6} \mathbf{b}$ were reoptimized by using several DFT functionals and the HF and MP2 $a b$ initio methods and the aug-cc-pVDZ basis set. MP4 single point calculations were carried out over the M11/aug-cc-pVDZ optimized geometries, and the enthalpy and Gibbs free energies were obtained from this same functional to add to MP2, MP4, and B2PLYP-D3 potential energies. DLPNO-CCSD(T)/aug-cc-pVTZ calculations were ran over the M11/aug-cc-pVDZ optimized geometries using the ORCA 4.2.1 program and were also corrected with the enthalpy and Gibbs free energies obtained from this same level. ${ }^{38}$

\section{ASSOCIATED CONTENT}

\section{Supporting Information}

The Supporting Information is available free of charge at https://pubs.acs.org/doi/10.1021/acs.joc.0c01338.

Details for the preparation of aldehyde 7, NMR spectra of all synthesized compounds, complete attribution of the ${ }^{1} \mathrm{H}$ and ${ }^{13} \mathrm{C}$ of compounds $\mathbf{6 b}$ and 9 with the analysis for assignment of their relative stereochemistries, Cartesian coordinates of compounds $\mathbf{6 a}$ and $\mathbf{6 b}$ global minima, their relative energies at different levels of theory, and of transition states TSa and TSb obtained at several $a b$ initio and DFT theoretical levels (PDF)

\section{AUTHOR INFORMATION}

\section{Corresponding Author}

Fernando Coelho - University of Campinas, Institute of Chemistry, Department of Organic Chemistry, 13083-970 Campinas, São Paulo, Brazil; ○ orcid.org/0000-0003-18001549; Email: facoelho@unicamp.br

\section{Authors}

Rodrigo A. Cormanich - University of Campinas, Institute of Chemistry, Department of Organic Chemistry, 13083-970 Campinas, São Paulo, Brazil; 다이.org/0000-0001-76591749

Lucas A. Zeoly - University of Campinas, Institute of Chemistry, Department of Organic Chemistry, 13083-970 Campinas, São Paulo, Brazil; @ orcid.org/0000-0003-2111-3904

Hugo Santos - University of Campinas, Institute of Chemistry, Department of Organic Chemistry, 13083-970 Campinas, São Paulo, Brazil; 이이이.org/0000-0002-7411-5180

Nilton S. Camilo - University of Campinas, Institute of Chemistry, Department of Organic Chemistry, 13083-970 Campinas, São Paulo, Brazil; † orcid.org/0000-0002-35212172

Michael Bühl - School of Chemistry, University of St Andrews, St Andrews, Fife KY169ST, U.K.; 이이.org/0000-00021095-7143

Complete contact information is available at: https://pubs.acs.org/10.1021/acs.joc.0c01338

\section{Notes}

The authors declare no competing financial interest.

\section{ACKNOWLEDGMENTS}

The authors are grateful to FAPESP for the financial support of this research. The authors also thank FAPESP for the fellowships to R.A.C. (\#2018/03910-1) and F.C. (\#2013/ 07600-3 and \#2018/02611-3) and for a scholarship to H.S. (\#2015/09205-0) and CNPq for a scholarship to L.A.Z. and a research fellowship for F.C, (307840/2014-0, 422890/2016-2 and 301330/2016-2). L.A.Z. also thanks Capes for a scholarship. CENAPAD-SP, CESUP, and SDumont computational resources are also gratefully acknowledged.

\section{REFERENCES}

(1) (a) Michael, J. P. Simple Indolizidine and Quinolizidine Alkaloids. In The Alkaloids: Chemistry and Biology; Knölker, H.-J., Ed.; Academic Press: 2016; Vol. 75, pp 1-498. (b) Michael, J. P. Indolizidine and Quinolizidine Alkaloids. Nat. Prod. Rep. 2008, 25, 139-165. (c) Gellert, E. The Indolizidine Alkaloids. J. Nat. Prod. 1982, 45, 50-73. 
(2) Sun, L.-R.; Wang, S.-X.; Li, X. A New Alkaloid from Polygonatum sibiricum. Zhongguo Yaowu Huaxue Zazhi 1997, 7, 129 (Chem. Abstr. 1999, 130, 2168).

(3) Quang, D. N.; Hashimoto, T.; Nukada, M.; Yamamoto, I.; Tanaka, M.; Asakawa, Y. Antioxidant Activity of Curtisians I - L from the Inedible Mushroom Paxillus curtisii. Planta Med. 2003, 69, 10631066.

(4) Sun, L.-R.; Li, X.; Wang, S.-W. Two New Alkaloids from the Rhizome of Polygonatum sibiricum. J. Asian Nat. Prod. Res. 2005, 7, 127-130.

(5) Sugimoto, K.; Toyoshima, K.; Nonaka, S.; Kotaki, K.; Ueda, H.; Tokuyama, H. Protecting-Group-Free Total Synthesis of (-)-Rhazinilam and (-)-Rhazinicine Using a Gold-Catalyzed Cascade Cyclization. Angew. Chem., Int. Ed. 2013, 52, 7168-7171.

(6) Gerasimenko, I.; Sheludko, Y.; Stöckigt, J. 3-Oxo-Rhazinilam: A New Indole Alkaloid from Rauvolfia Serpentina x Rhazya Stricta Hybrid Plant Cell Cultures. J. Nat. Prod. 2001, 64, 114-116.

(7) David, B.; Sévenet, T.; Morgat, M.; Guénard, D.; Moisand, A.; Tollon, Y.; Thoison, O.; Wright, M. Rhazinilam Mimics the Cellular Effects of Taxol by Different Mechanisms of Action. Cell Motil. Cytoskeleton 1994, 28, 317-326.

(8) For recent examples of the syntheses of 5,6,7,8-tetrahydroindolizines, see: (a) Biletzki, T.; Imhof, W. Catalytic One-Pot Synthesis of 1-Substituted 5,6,7,8-Tetrahydroindolizine Derivatives. Eur. J. Org. Chem. 2012, 2012, 6513-6516. (b) Ortega, N.; Tang, D.-T. D.; Urban, S.; Zhao, D.; Glorius, F. Ruthenium-NHC-Catalyzed Asymmetric Hydrogenation of Indolizines: Access to Indolizidine Alkaloids. Angew. Chem., Int. Ed. 2013, 52, 9500-9503. (c) Zhou, Y.; Liu, X.-W.; Gu, Q.; You, S.-L. Enantioselective Synthesis of Tetrahydroindolizines via Ruthenium- Chiral Phosphoric Acid Sequential Catalysis. Synlett 2016, 27, 586-590. (d) Capomolla, S. S.; Lim, N.-K.; Zhang, H. Single-Step Synthesis of 5,6,7,8Tetrahydroindolizines via Annulation of 2-Formylpiperidine and 1,3-Dicarbonyl Compounds. Org. Lett. 2015, 17, 3564-3567 and references cited therein. (e) Iwase, S.; Suzuki, Y.; Tanaka, S.; Kitamura, M. CpRu/Brønsted Acid-Catalyzed Enantioselective Dehydrative Cyclization of Pyrroles N-Tethered with Allylic Alcohols. Org. Lett. 2020, 22, 1929-1933.

(9) Teodoro, B. V. M.; Correia, J. T. M.; Coelho, F. Selective Hydrogenation of Indolizines: An Expeditious Approach to Derive Tetrahydroindolizines and Indolizidines from Morita-Baylis-Hillman Adducts. J. Org. Chem. 2015, 80, 2529-2538.

(10) (a) Jefford, C. W.; Johncock, W. 269. Intramolecular Carbenoid Reactions of Pyrrole Derivatives Efficient Syntheses of Pyrrolizinone and Dihydroindolizinone. Helv. Chim. Acta 1983, 66, 2666-2671. (b) Jefford, C. W.; Zaslona, A. Competitive Intramolecular Carbenoid Reactions of Pyrrole Derivatives. Tetrahedron Lett. 1985, 26, 60356038. (c) Jefford, C. W.; Tang, Q.; Zaslona, A. Short, Enantiogenic Syntheses of (-)-Indolizidine 167B and (+)-Monomorine. J. Am. Chem. Soc. 1991, 113, 3513-3518. (d) Beck, E. M.; Hatley, R.; Gaunt, M. J. Synthesis of Rhazinicine by a Metal-Catalyzed C-H Bond Functionalization Strategy. Angew. Chem., Int. Ed. 2008, 47, 3004-3007. (e) Conrad, J. C.; Kong, J.; Laforteza, B. N.; MacMillan, D. W. C. Enantioselective a-Arylation of Aldehydes via OrganoSOMO Catalysis. An Ortho-Selective Arylation Reaction Based on an Open-Shell Pathway. J. Am. Chem. Soc. 2009, 131, 11640-11641. (f) Cavitt, M. A.; France, S. Aluminum(III)-Catalyzed, Formal Homo-Nazarov-Type Ring-Opening Cyclizations toward the Synthesis of Functionalized Tetrahydroindolizines. Synthesis 2016, 48, 1910-1919 and references cited therein. (g) Bhusal, R. P.; Sperry, J. Flexible synthesis of diverse $\mathrm{N}$-heterocycles from substrates attainable from biomass. Green Chem. 2016, 18, 2453-2459.

(11) (a) Jefford, C. W.; Thornton, S. R.; Sienkiewicz, K. An Enantiospecific Entry to Indolizidines by Intramolecular Acylation of N-Pyrrole Esters. Tetrahedron Lett. 1994, 35, 3905-3908. (b) Barton, D. H. R.; Pereira, M. M. M. A.; Taylor, D. K. A Simple Route to the Indolizidine Alkaloid Skeleton. Tetrahedron Lett. 1994, 35, 91579158. (c) Jefford, C. W.; Sienkiewicz, K.; Thornton, S. R. 116. Short, Enantiospecific Syntheses of Indolizidines 209B and 209D, and
Piclavine A from Diethyl-L-Glutamate. Helv. Chim. Acta 1995, 78, 1511-1524. (d) Dinsmore, A.; Mandy, K.; Michael, J. P. Total Synthesis of Two Novel 5,6,7,8-Tetrahydroindolizine Alkaloids, Polygonatines A and B. Org. Biomol. Chem. 2006, 4, 1032-1037. (e) Reddy, C. R.; Reddy, M. D.; Srikanth, B. Phosphine-Mediated Cascade Reaction of Azides with MBH-Acetates of Acetylenic Aldehydes to Substituted Pyrroles: A Facile Access to N-Fused Pyrrolo-Heterocycles. Org. Biomol. Chem. 2012, 10, 4280-4288. (f) Corvo, M. C.; Pereira, M. M. A. A Radical Approach Towards Indolizidine 167B. Tetrahedron Lett. 2002, 43, 455-458. (g) Gracia, S.; Jerpan, R.; Pellet-Rostaing, S.; Popowycz, F.; Lemaire, M. Straightforward synthesis of indolizidine alkaloid 167B. Tetrahedron Lett. 2010, 51, 6290-6293. (h) Zhang, S.; Taylor, J. E.; Slawin, A. M. Z.; Smith, A. D. Isothiourea-Catalyzed Enantioselective Functionalization of 2-Pyrrolyl Acetic Acid: Two-Step Synthesis of Stereodefined Dihydroindolizinones. Org. Lett. 2018, 20, 5482-5485. (i) Allin, S. M.; Barton, W. R. S.; Bowman, W. R.; McInally, T. Acyl Radical Cyclisation onto Pyrroles. Tetrahedron Lett. 2001, 42, 7887-7890. (j) Du, X.-W.; Ghosh, A.; Stanley, L. M. Enantioselective Synthesis of Polycyclic Nitrogen Heterocycles by Rh-Catalyzed Alkene Hydroacylation: Constructing Six-Membered Rings in the Absence of Chelation Assistance. Org. Lett. 2014, 16, 4036-4039. (k) Yao, J.-N.; Liang, X.; Wei, K.; Yang, Y.-R. Catalytic, Enantioselective Formal Synthesis of Monoterpene Indole Alkaloid (-)-Alstoscholarine. Org. Lett. 2019, 21, 8485-8487.

(12) Pyridoxine hydrochloride and its analogues have significant biological roles in living organisms. For some articles concerning biochemical applications of these substances, see: (a) Korytnyk, W. Synthesis and Biological Activity of Vitamin B6 Analogs. Methods Enzymol. 1979, 62, 454-483. (b) Shtyrlin, Y. G.; Petukhov, A. S.; Strelnik, A. D.; Shtyrlin, N. V.; Iksanova, A. G.; Pugachev, M. V.; Pavelyev, R. S.; Dzyurkevich, M. S.; Garipov, M. R.; Balakin, K. V. Chemistry of Pyridoxine in Drug Design. Russ. Chem. Bull. 2019, 68, 911-945 and references cited herein..

(13) Korytnyk, W.; Srivastava, S. C.; Angelino, N.; Potti, P. G. G.; Paul, B. Chemistry and Biology of Vitamin B6. 33. General Method for Modifying the 2-Methyl Group of Pyridoxol. Synthesis and Biological Activity of 2-Vinyl- and 2-Ethynylpyridoxols and Related Compounds. J. Med. Chem. 1973, 16, 1096-1101.

(14) Coelho, F.; Almeida, W. P.; Veronese, D.; Mateus, C. R.; Silva Lopes, E. C.; Rossi, R. C.; Silveira, G. P. C.; Pavam, C. H. Ultrasound in Baylis-Hillman Reactions with Aliphatic and Aromatic Aldehydes: Scope and Limitations. Tetrahedron 2002, 58, 7437-7447.

(15) (a) Bode, M. L.; Kaye, P. T. A New Synthesis of Indolizines via Thermal Cyclisation of 2-Pyridyl Derivatives. J. Chem. Soc., Perkin Trans. 1 1990, 1, 2612-2613. (b) Bode, M. L.; Kaye, P. T. Indolizine Studies. Part 2. Synthesis and NMR Spectroscopic Analysis of 2Substituted Indolizines. J. Chem. Soc., Perkin Trans. 1 1993, 18091813.

(16) Haasnoot, C. A. G.; de Leeuw, F. A. A. M.; Altona, C. The Relationship Between Proton-Proton NMR Coupling Constants and Substituent Electronegativities-I. An Empirical Generalization of the Karplus Equation. Tetrahedron 1980, 36, 2783-2792.

(17) Anet, F. A. L.; Bourn, A. J. R. Nuclear Magnetic Resonance Spectral Assignments from Nuclear Overhauser Effects. J. Am. Chem. Soc. 1965, 87, 5250-5251.

(18) (a) Llàcer, E.; Romea, P.; Urpí, F. Studies on the Hydrogenolysis of Benzyl Ethers. Tetrahedron Lett. 2006, 47, 58155818. (b) Hagishita, S.; Yamada, M.; Shirahase, K.; Okada, T.; Murakami, Y.; Ito, Y.; Matsuura, T.; Wada, M.; Kato, T.; Ueno, M.; Chikazawa, Y.; Yamada, K.; Ono, T.; Teshirogi, I.; Ohtani, M. Potent Inhibitors of Secretory Phospholipase A2: Synthesis and Inhibitory Activities of Indolizine and Indene Derivatives. J. Med. Chem. 1996, 39, 3636-3658.

(19) Grimme, S. Improved Second-Order Møller-Plesset Perturbation Theory by Separate Scaling of Parallel- and Antiparallel-Spin Pair Correlation Energies. J. Chem. Phys. 2003, 118, 9095-9102.

(20) Zhao, Y.; Truhlar, D. G. The M06 Suite of Density Functionals for Main Group Thermochemistry, Thermochemical Kinetics, 
Noncovalent Interactions, Excited States, and Transition Elements: Two New Functionals and Systematic Testing of Four M06-Class Functionals and 12 Other Function. Theor. Chem. Acc. 2008, 120, 215-241.

(21) Peverati, R.; Truhlar, D. G. Improving the Accuracy of Hybrid Meta-GGA Density Functionals by Range Separation. J. Phys. Chem. Lett. 2011, 2, 2810-2817.

(22) Grimme, S. Semiempirical Hybrid Density Functional with Perturbative Second-Order Correlation. J. Chem. Phys. 2006, 124, No. 034108

(23) Neese, F.; Schwabe, T.; Kossmann, S.; Schirmer, B.; Grimme, S. Assessment of Orbital-Optimized, Spin-Component Scaled SecondOrder Many-Body Perturbation Theory for Thermochemistry and Kinetics. J. Chem. Theory Comput. 2009, 5, 3060-3073.

(24) Bachorz, R. A.; Bischoff, F. A.; Höfener, S.; Klopper, W.; Ottiger, P.; Leist, R.; Frey, J. A.; Leutwyler, S. Scope and Limitations of the SCS-MP2Method for Stacking and Hydrogen Bonding Interactions. Phys. Chem. Chem. Phys. 2008, 10, 2758-2766.

(25) Iron, M. A.; Oren, M.; Martin, J. A. N. M. L. Alkali and Alkaline Earth Metal Compounds: Core-Valence Basis Sets and Importance of Subvalence Correlation. Mol. Phys. 2003, 101, 1345-1361.

(26) Feller, D.; Peterson, K. A.; Grant Hill, J. On the Effectiveness of $\operatorname{CCSD}(\mathrm{T})$ Complete Basis Set Extrapolations for Atomization Energies. J. Chem. Phys. 2011, 135, No. 044102.

(27) Trucks, G. W.; Salter, E. A.; Sosa, C.; Bartlett, R. J. Theory and implementation of the MBPT density matrix. An application to oneelectron properties. Chem. Phys. Lett. 1988, 147, 359-366.

(28) Riplinger, C.; Sandhoefer, B.; Hansen, A.; Neese, F. Natural Triple Excitations in Local Coupled Cluster Calculations with Pair Natural Orbitals. J. Chem. Phys. 2013, 139, 134101.

(29) Riplinger, C.; Neese, F. An Efficient and near Linear Scaling Pair Natural Orbital Based Local Coupled Cluster Method. J. Chem. Phys. 2013, 138, No. 034106.

(30) Liakos, D. G.; Sparta, M.; Kesharwani, M. K.; Martin, J. M. L.; Neese, F. Exploring the Accuracy Limits of Local Pair Natural Orbital Coupled-Cluster Theory. J. Chem. Theory Comput. 2015, 11, 15251539.

(31) McCann, B. W.; McFarland, S.; Acevedo, O. Benchmarking Continuum Solvent Models for Keto-Enol Tautomerizations. J. Phys. Chem. A 2015, 119, 8724-8733.

(32) Bandyopadhyay, B.; Pandey, P.; Banerjee, P.; Samanta, A. K.; Chakraborty, T. $\mathrm{CH} \cdots \mathrm{O}$ Interaction Lowers Hydrogen Transfer Barrier to Keto-Enol Tautomerization of $\beta$-Cyclohexanedione: Combined Infrared Spectroscopic and Electronic Structure Calculation Study. J. Phys. Chem. A 2012, 116, 3836-3845.

(33) da Silva, G. Carboxylic Acid Catalyzed Keto-Enol Tautomerizations in the Gas Phase. Angew. Chem., Int. Ed. 2010, 49, 7523-7525.

(34) Du, B.; Zhang, W. Catalytic Effect of Water, Water Dimer, or Formic Acid on the Tautomerization of Nitroguanidine. Comput. Theor. Chem. 2014, 1049, 90-96.

(35) Shao, Y.; Molnar, L. F.; Jung, Y.; Kussmann, J.; Ochsenfeld, C.; Brown, S. T.; Gilbert, A. T. B.; Slipchenko, L. V.; Levchenko, S. V.; O’Neill, D. P.; DiStasio, R. A., Jr.; Lochan, R. C.; Wang, T.; Beran, G. J. O.; Besley, N. A.; Herbert, J. M.; Lin, C. Y.; Van Voorhis, T.; Chien, S. H.; Sodt, A.; Steele, R. P.; Rassolov, V. A.; Maslen, P. E.; Korambath, P. P.; Adamson, R. D.; Austin, B.; Baker, J.; Byrd, E. F. C.; Dachsel, H.; Doerksen, R. J.; Dreuw, A.; Dunietz, B. D.; Dutoi, A. D.; Furlani, T. R.; Gwaltney, S. R.; Heyden, A.; Hirata, S.; Hsu, C.-P.; Kedziora, G.; Khalliulin, R. Z.; Klunzinger, P.; Lee, A. M.; Lee, M. S.; Liang, W. Z.; Lotan, I.; Nair, N.; Peters, B.; Proynov, E. I.; Pieniazek, P. A.; Rhee, Y. M.; Ritchie, J.; Rosta, E.; Sherrill, C. D.; Simmonett, A. C.; Subotnik, J. E.; Woodcock, H. L., III; Zhang, W.; Bell, A. T.; Chakraborty, A. K.; Chipman, D. M.; Keil, F. J.; Warshel, A.; Hehre, W. J.; Schaefer, H. F.; Kong, J.; Krylov, A. I.; Gill, P. M. W.; HeadGordon, M. Phys. Chem. Chem. Phys. 2006, 8, 3172-3191.

(36) Frisch, M. J.; Trucks, G. W.; Schlegel, H. B.; Scuseria, G. E.; Robb, M. A.; Cheeseman, J. R.; Scalmani, G.; Barone, V.; Mennucci, B.; Petersson, G. A.; Nakatsuji, H.; Caricato, M.; Li, X.; Hratchian, H. P.; Izmaylov, A. F.; Bloino, J.; Zheng, G.; Sonnenberg, J. L.; Hada, M.;
Ehara, M.; Toyota, K.; Fukuda, R.; Hasegawa, J.; Ishida, M.; Nakajima, T.; Honda, Y.; Kitao, O.; Nakai, H.; Vreven, T.; Montgomery, J. A., Jr.; Peralta, J. E.; Ogliaro, F.; Bearpark, M.; Heyd, J. J.; Brothers, E.; Kudin, K. N.; Staroverov, V. N.; Kobayashi, R.; Normand, J.; Raghavachari, K.; Rendell, A.; Burant, J. C.; Iyengar, S. S.; Tomasi, J.; Cossi, M.; Rega, N.; Millam, J. M.; Klene, M.; Knox, J. E.; Cross, J. B.; Bakken, V.; Adamo, C.; Jaramillo, J.; Gomperts, R.; Stratmann, R. E.; Yazyev, O.; Austin, A. J.; Cammi, R.; Pomelli, C.; Ochterski, J. W.; Martin, R. L.; Morokuma, K.; Zakrzewski, V. G.; Voth, G. A.; Salvador, P.; Dannenberg, J. J.; Dapprich, S.; Daniels, A. D.; Farkas, Ö.; Foresman, J. B.; Ortiz, J. V.; Cioslowski, J.; Fox, D. J. Gaussian 09, revision D.01; Gaussian, Inc.: Wallingford, CT, 2009.

(37) Scalmani, G.; Frisch, M. J.; Scalmani, G.; Frisch, M. J. Continuous surface charge polarizable continuum models of solvation. I. General formalism. J. Chem. Phys. 2010, 132, 114110.

(38) Neese, F. The ORCA Program System. Wiley Interdiscip. Rev.: Comput. Mol. Sci. 2012, 2, 73-78. 